\title{
Rumen degradability and ileal digestibility of proteins and amino acids of feedstuffs for cows
}

\author{
Iveta Maskal’ová, Vladimír Vajda, Marek Krempaský, Lukáš Bujňák \\ University of Veterinary Medicine and Pharmacy in Košice, Department of Animal Nutrition, \\ Dietetics and Animal Breeding, Košice, Slovak Republic \\ Received January 30, 2014 \\ Accepted April 24, 2014
}

\begin{abstract}
Knowledge of the profile of amino acids of the rumen-undegradable protein can help in the formulation of diets to provide amino acids that complement microbial protein as well as supply amino acids, which are most limiting for milk production. Three non-lactating cows fitted with rumen cannulas were used to determine the effect of in situ rumen degradation on crude protein and amino acid profile of rumen-undegraded protein of feedstuffs. The obtained values of rumen degradability of crude protein with significant difference $(P<0.001)$ between feeds ranged from 20.3 to $76.3 \%$ (mean $62.0 \pm 17.9 \%$ ) and values of total amino acids ranged from $30.9 \%$ in corn gluten meal to $83.8 \%$ in corn gluten feed (mean $67.5 \pm 16.4 \%$ ). An in vitro modified 3-step method was used to determine intestinal digestibility. Intestinal digestibility of undegraded protein varied from $54.5 \pm 1.4 \%$ in raw soybean to $95.2 \pm 1.0 \%$ in corn gluten feed. The absorbable amino acid profile of rumen-undegraded protein for each feedstuff was compared with profiles of the original feedstuff and the rumen-exposed undegraded protein. Absorbable lysine $(9.3 \pm 1.1 \mathrm{~g} / \mathrm{kg}$ of crude protein) was higher in products of soybean and sunflower cake. Corn gluten feed and meal supplied more absorbable methionine $(3.6 \pm 0.6 \mathrm{~g} / \mathrm{kg}$ of crude protein). This study showed that the digestibility factor of crude protein and amino acid based on in situ and in vitro methods for thermal treatment of protein feeds can be used in models to optimize the amino acid nutrition of dairy cows and expand knowledge about rumen degradability and ileal digestibility of amino acids in feedstuffs.
\end{abstract}

Rumen degradation, undegradable, intestinal, thermal treatment, milk protein

A limiting factor of protein nutrition in cows is lower utilization of nitrogen $(\mathrm{N})$. Overall average efficiency of utilization of $\mathrm{N}(\mathrm{N} g$ feed/g $\mathrm{N}$ intake) in dairy cows with high production is approximately $25 \%$ (Huhtanen and Hristov 2009). The total milk yield and milk protein production in high-producing dairy cows is limited due to inadequate intake of certain amino acids. The most limiting amino acids for synthesis of milk protein were reported to be lysine (Lys) and methionine (Met) (Rulquin et al. 2001). More recent studies confirm the content of histidine and leucine amino acids as potentially limiting for milk protein synthesis. The amino acid profile of the intestinal contents in dairy cows depends on the amino acid (AA) content of microbial protein as well as rumen undegradable protein (RUP) and their intestinal digestibility (Rulqiun et al. 2001). The amino acid profile and intestinal digestibility of individual AA of RUP vary widely among and within feedstuffs (Prestlokken and Rise 2003; Mjoun et al. 2010). Using the small intestinal digestibility of RUP as a constant factor will lead to errors in prediction of nutrient needs. Therefore, intestinal digestibility of RUP has become an important variable in recent protein evaluation systems for ruminants (Hvelplund and Nørgaard 2003). Current feed evaluation and formulation is generally based on mean table values for the content and digestibility of AA of the individual feedstuffs. New approaches for analysis of digestible AA based on rapid in vitro and in situ analysis technique appear to result in more correct estimates of the actual nutritional needs. 
The main objectives of this study were to determine the rumen degradation and intestinal digestibility of crude protein, AA composition of RUP, and intestinal digestibility of the AA in RUP from several feedstuffs with high crude protein concentration.

\section{Materials and Methods}

Feedstuffs

Different protein concentrates routinely used in Slovakia were examined: raw soybean (RS), soybean meal (SM), Hyterso (toasted soybean - TS), Soypass (soybean meal treated with xylose - SP), corn gluten meal (CGM), corn gluten feed (CGF), rapeseed cake (RC), sunflower cake (SC), brewers grain dehydrated (BGD), malt culms $(\mathrm{MC})$.

\section{Animals and in situ rumen incubation}

Indicators of rumen degradation of crude protein (CP) were determined, using in situ methods (Orskov and McDonald 1979), where $5 \mathrm{~g}$ of sample of each feed was weighed into bags $(10 \times 20 \mathrm{~cm}, 53 \pm 10 \mu \mathrm{m}$ pore size R1020 ANKOM technology, Macedon, NY) and heat-sealed. Samples of each feedstuff were incubated in duplicate, in the rumen of each cow for $0,3,6,9,12$, and $24 \mathrm{~h}$. The in situ procedure was conducted using 3 nonlactating dairy cows (600 kg of body weight) fitted with rumen cannulas. Animals were fed a lactation diet $a d$ libitum (CP 15.0\%, neutral detergent fibre 36.8\%, and acid detergent fibre $25.3 \%$ of dry matter) composed of $53 \%$ forage and $47 \%$ of concentrate. After ruminal degradation, bags were rinsed with cold water to remove particulate matter. The intestinal digestibility of RUP of selected protein feeds was performed by modified three-step method (MTSP) (Gargallo et al. 2006). Approximately $1.0 \mathrm{~g}$ of the pooled rumen-exposed residue after $12 \mathrm{~h}$ rumen incubation were weighed into nylon bags $(5 \times 10 \mathrm{~cm}, 50 \mu \mathrm{m}$ pore size, R 510 ANKOM Technology), heat-sealed and placed in a Daisy ${ }^{I I}$ incubator (ANKOM, Fairport, NY, USA). Samples were incubated in 21 of pre-warmed $0.1 \mathrm{~N} \mathrm{HCl}$ solution adjusted to $\mathrm{pH} 1.9$ and containing $1 \mathrm{~g} / 1$ of pepsin (P-7000, Sigma, St. Louis, MO, USA). They were rotated constantly at $39^{\circ} \mathrm{C}$ for $1 \mathrm{~h}$. After pepsin digestion, samples were rinsed in cold tap water until the runoff was clear before they were incubated in 21 of pre-warmed pancreatin (Sigma P-7545, St. Louis, MO, USA) solution $\left(0.5 \mathrm{M} \mathrm{KH}_{2} \mathrm{PO}_{4}\right.$ buffer standardized at $\mathrm{pH} 7.8$ and containing $50 \mathrm{ppm}$ of thymol and $3 \mathrm{~g} / 1$ of pancreatin) and rotated constantly at $39^{\circ} \mathrm{C}$ for $24 \mathrm{~h}$. After incubation, samples were rinsed in cold tap water until the runoff was clear and oven-dried at $55^{\circ} \mathrm{C}$ for $48 \mathrm{~h}$.

\section{Chemical analysis}

Samples of feeds and bag residues after ruminal degradation and ileal digestion were analyzed for AA using the AAA 400 analyzer of amino acids (INGOS, Czech Republic). The methods incorporated an ion-exchange column, multiple sequential sodium-based eluents, and sodium hydroxide, for column regeneration. Absorbance was measured following post-column colour development by ninhydrin reagent at $131^{\circ} \mathrm{C}$. All individual AA were calculated on the basis of quantification by acid-stable hydrolysis $\left(6 \mathrm{~N} \mathrm{HCl}\right.$ at $110{ }^{\circ} \mathrm{C}$ for $\left.24 \mathrm{~h}\right)$ and the cystine and methionine contents were also quantified by means of performic acid hydrolyzed AA analysis. Feed samples were analyzed for dry matter (DM), crude protein (CP), crude fibre (CF), and ether extract (EE) according to conventional methods (Committee Regulation ES No.152/2009). Dry matter was determined by weight upon drying the sample at $105{ }^{\circ} \mathrm{C}$ under prescribed conditions. The $\mathrm{CP}$ content was determined according to the Kjeldahl methods $(\mathrm{N} \times 6.25)$ using a 2300 Kjeltec Analyser Unit (Foss Tecator AB, Hoganas, Sweden). Fat (as etheric extract) was determined by the Det-gras device (JP SELECTA, Spain). Crude fibre was determined by the Dosi-Fibre Analyzer device (JP SELECTA, Spain).

The results were processed by mathematical-statistical methods using the statistical program GraphPad Prism4. We evaluated results of rumen degradation of $\mathrm{CP}$ and individual AA, their ileal digestibility and their differences for each feed as variable using Tukey-HSD test at significance levels of $P \leq 0.01$ and $P \leq 0.05$. Each indicator was presented by its mean $(\mathrm{x})$, standard deviation (SD) and standard error of means (SEM).

\section{Results}

Chemical analysis of nutrients and calculated nutritional value of feeds tested in the experiment is shown in Table 1. The DM content ranged from 864 to $953.9 \mathrm{~g} / \mathrm{kg}$. The $\mathrm{CP}$ content of selected feeds varied from 205.7 to $748.4 \mathrm{~g} / \mathrm{kg}$ of DM with different AA profile among feedstuffs. As expected, there was a large range in EE content among all feedstuffs $(6.61-214.2 \mathrm{~g} / \mathrm{kg}$ of DM). Concentration of total of CP with mean $878.4 \pm$ $76.6 \mathrm{~g} \mathrm{AA} / \mathrm{kg}$ of CP and concentration of essential AA (EAA) g/kg CP with mean 417.9 $\pm 55.1 \mathrm{~g} / \mathrm{kg}$ of CP (Table 1) does not differ among feeds. The fraction of EAA in total AA was higher in soybean meal $(489.8 \mathrm{~g} / \mathrm{kg}$ of CP) but lower in malt culms $(325.2 \mathrm{~g} / \mathrm{kg}$ of $\mathrm{CP}$ ). 
Table 1 . Chemical analysis of nutrients of experimental feeds in $\mathrm{g} / \mathrm{kg}$ of dry matter.

\begin{tabular}{lccrrrrr}
\hline Feedstuffs & DM & CP & EE & CF & PDI & $\begin{array}{c}\text { Total AA } \\
\text { g/kg CP }\end{array}$ & $\begin{array}{c}\text { EAA } \\
\text { g/kg CP }\end{array}$ \\
\hline Raw soybean & 920.2 & 319.4 & 188.3 & 163.5 & 82.2 & 926.3 & 459.1 \\
Soybean meal & 878.5 & 520.0 & 12.4 & 49.9 & 242.5 & 957.7 & 489.8 \\
Hyterso & 900.0 & 386.0 & 214.2 & 113.0 & 222.0 & 877.1 & 439.4 \\
Soypass & 864.9 & 501.3 & 47.2 & 51.1 & 307.4 & 867.7 & 433.2 \\
Sunflower cake & 953.9 & 352.0 & 79.4 & 187.7 & 146.2 & 944.3 & 459.8 \\
Rapeseed cake & 919.5 & 376.2 & 74.2 & 133.4 & 132.5 & 835.5 & 417.8 \\
Malt culms & 928.5 & 285.3 & 11.5 & 90.6 & 114.2 & 710.2 & 325.2 \\
Brewers grains & 941.3 & 278.3 & 73.3 & 198.8 & 192.3 & 860.5 & 354.8 \\
Corn gluten feed & 885.7 & 205.7 & 16.1 & 81.3 & 129.5 & 838.7 & 350.8 \\
Corn gluten meal & 921.7 & 748.7 & 6.61 & 9.1 & 529.5 & 966.3 & 499.0 \\
\hline
\end{tabular}

$\mathrm{DM}$ - dry matter, $\mathrm{CP}$ - crude protein, EE - ether extract, $\mathrm{CF}$ - crude fibre, PDI - protein digestible in intestine, AA - amino acid, EAA - essential amino acid

Results of rumen degradability of proteins (RDP) obtained by the in-situ method (Table 2) showed a considerable effect of the time of feed incubation in the rumen environment and effect of the type of feed and the way of its treatment. Thermal treatment of soybeanbased feed has a significant effect on degradability of CP compared to RS (76.0\%), reaching $46.5 \%$ with Soypass (SP). Rapeseed cake and, particularly, shelled sunflower cake showed a mean degradability of CP equal to $60.5 \%$ and $53.1 \%$, respectively. Byproducts such as BGD, MC and CGF with a proportion of CP at the level of $20-30 \%$ showed rumen degradability of 74.5-76.3\%. Corn gluten meal with the proportion of $\mathrm{CP}$ at the level of $748 \mathrm{~g} / \mathrm{kg}$ of DM showed very high resistance to the action of rumen microflora with degradability at the level of $20.3 \%$. Intestinal digestibility of CP (IDP) of RUP (Table 2 ) was estimated by the modified method described by Gargallo et al. (2006). The mean

Table 2. Protein digestibility of experimental feeds.

\begin{tabular}{lcccc}
\hline Feedstuffs & RDP $(\%)$ & IDP $\%$ of CP & IADP \% of CP & TDP \% of CP \\
\hline Raw soybean & $76.0 \pm 8.8$ & $54.5 \pm 1.4$ & $13.1 \pm 4.2$ & $89.1 \pm 4.6$ \\
Soybean meal & $71.0 \pm 1.8$ & $90.1 \pm 0.6$ & $26.1 \pm 1.4$ & $97.1 \pm 0.4$ \\
Hyterso & $66.8 \pm 5.6$ & $80.9 \pm 0.4$ & $26.9 \pm 5.3$ & $93.7 \pm 0.3$ \\
Soypass & $46.5 \pm 1.7$ & $62.8 \pm 0.1$ & $33.4 \pm 1.6$ & $80.2 \pm 0.1$ \\
Sunflower cake & $53.1 \pm 0.8$ & $90.2 \pm 0.1$ & $42.3 \pm 0.6$ & $95.4 \pm 0.1$ \\
Rapeseed cake & $60.5 \pm 3.1$ & $81.3 \pm 1.4$ & $32.1 \pm 1.9$ & $92.6 \pm 1.2$ \\
Malt culms & $76.3 \pm 2.4$ & $74.0 \pm 4.0$ & $17.5 \pm 0.1$ & $93.8 \pm 2.4$ \\
Brewers grains & $74.5 \pm 1.4$ & $70.2 \pm 1.8$ & $17.9 \pm 0.1$ & $92.4 \pm 1.2$ \\
Corn gluten feed & $74.8 \pm 0.1$ & $95.2 \pm 1.9$ & $24.0 \pm 0.7$ & $98.8 \pm 0.4$ \\
Corn gluten meal & $20.3 \pm 0.5$ & $84.7 \pm 7.3$ & $67.5 \pm 6.4$ & $87.8 \pm 8.3$ \\
X \pm SD & $62.0 \pm 17.9$ & $78.4 \pm 13.0$ & $30.1 \pm 15.7$ & $92.1 \pm 5.3$ \\
SEM & 5.662 & 4.101 & 4.969 & 1.685 \\
\hline
\end{tabular}

RDP - rumen degradable protein, IDP - intestinal digestibility of protein, CP - crude protein, IADP - intestinally absorbable dietary protein, TDP - total tract digestibility of crude protein (Mjoun et al. 2010) X - mean, SD - standard deviation, SEM - standard error mean 
intestinal digestibility of $\mathrm{CP}$ was $78.4 \pm 13.0 \%$. Rumen degradability of $\mathrm{CP}$ as well as intestinal digestibility of CP of RUP in experimental protein feeds was much more variable $(P<0.01)$.

Intestinally absorbable digestible protein - IADP was calculated as multiplying amount of RUP with IDP. After determination of CP of RUP and IDP, the mean of IADP was $30.1 \pm$ $15.7 \%$ (Table 2), with more variable values of IADP found between feeds. Values of IADP ranged from $13.1 \pm 4.2$ to $67.5 \pm 6.4 \%$ for RS and CGM, respectively.

Total tract digestibility of crude protein (TDP) was calculated as sum of RDP and IADP. The mean total digestibility in tested feeds was $92.1 \pm 5.3 \%$. There was a small but significant difference $(P<0.05)$ in the total digestibility of protein of feedstuffs (Table 2$)$. Total tract digestibility of crude protein of Soypass was lower than $85 \%$; it was only one from all selected feeds. The total digestibility of protein varied from $80.2 \%$ for Soypass to $98.8 \%$ for CGF.

Table 3. Coefficients of ruminal degradability and ileal digestibility of total and essential amino acids.

\begin{tabular}{lcccc}
\hline Feedstuffs & \multicolumn{2}{c}{ Rumen degradability } & \multicolumn{2}{c}{ Intestinal digestibility } \\
& Total AA & EAA & Total AA & EAA \\
\hline Raw soybean & 0.789 & 0.786 & 0.633 & 0.657 \\
Soybean meal & 0.749 & 0.753 & 0.907 & 0.908 \\
Hyterso & 0.680 & 0.680 & 0.854 & 0.881 \\
Soypass & 0.526 & 0.531 & 0.632 & 0.629 \\
Sunflower cake & 0.616 & 0.611 & 0.903 & 0.905 \\
Rapeseed cake & 0.632 & 0.632 & 0.821 & 0.826 \\
Malt culms & 0.790 & 0.784 & 0.887 & 0.903 \\
Brewers grains & 0.825 & 0.824 & 0.762 & 0.763 \\
Corn gluten feed & 0.838 & 0.834 & 0.951 & 0.950 \\
Corn gluten meal & 0.309 & 0.312 & 0.839 & 0.833 \\
X \pm SD & $0.675 \pm 0.2$ & $0.675 \pm 0.2$ & $0.819 \pm 0.1$ & $0.825 \pm 0.1$ \\
SEM & 0.052 & 0.051 & 0.035 & 0.035 \\
\hline
\end{tabular}

$\mathrm{X}$ - mean, SD - standard deviation, SEM - standard error mean, AA - amino acid, EAA - essential amino acid

The coefficients of the intestinal digestibility of total AA (Table 3) in protein feeds determined by the MTSP procedure were in relationship to the ileal digestibility of CP. Overall, ruminal degradation of total AA and EAA degradation (Table 3) reflected the overall pattern of CP. Rumen degradation of total AA (Table 3), respective AA (data not presented) varied considerably among and within feedstuffs. Mean coefficients of rumen degradability of total AA (Table 3$)(0.675 \pm 0.2)$ were significantly higher $(P<0.001)$ than rumen degradability of CP $(0.620 \pm 0.2)$. The mean of intestinal digestibility of CP of RUP was $78.4 \pm 13.0 \%$ (Table 2), which is similar and without significant difference to the mean of intestinal digestibility of total AA of RUP $(81.9 \pm 11.7 \%)$. Intestinal digestibility of RUP and total AA of RUP in experimental feedstuffs was greater for SM, SC and CGF with mean of $91.8 \pm 2.9 \%$ compared to remaining feeds, with the mean of $76.3 \pm 7.5 \%$. Effective degradability of Lys was generally very close to degradability of total AA with mean of $84.1 .1 \pm 12.4 \%$ (data not presented), whereas degradability of Met deviated little from the effective degradability of total AA $(79.7 \pm 12.0 \%)$.

The estimated intestinally absorbable amount of each EAA ( $\mathrm{g} / \mathrm{kg}$ of CP) supplied by the RUP fraction of protein feeds is presented in Table 4. Absorbable Lys was greatest 
Table 4. Intestinally absorbable essential amino acids supplied by the rumen undegradable protein of feedstuffs.

\begin{tabular}{lrrrrrrrrrr}
\hline AA g/kg of CP & \multicolumn{1}{c}{ RS } & \multicolumn{1}{c}{ SM } & \multicolumn{1}{c}{ TS } & \multicolumn{1}{c}{ SP } & SC & RC & MC & BGD & CGF & CGM \\
\hline Lysine (Lys) & 10.5 & 10.1 & 9.5 & 8.5 & 8.0 & 6.0 & 7.6 & 7.4 & 5.6 & 4.2 \\
Histidine (His) & 4.1 & 4.6 & 2.7 & 4.3 & 4.6 & 3.2 & 1.9 & 3.9 & 4.3 & 2.1 \\
Arginine (Arg) & 9.7 & 12.5 & 10.5 & 9.3 & 11.7 & 5.1 & 4.7 & 6.8 & 6.3 & 5.5 \\
Threonine (Thr) & 1.4 & 5.6 & 3.9 & 4.5 & 6.3 & 4.9 & 2.7 & 5.4 & 6.5 & 4.4 \\
Valine (Val) & 7.1 & 8.1 & 6.7 & 6.3 & 8.2 & 5.6 & 6.3 & 7.8 & 9.6 & 3.6 \\
Methionine (Met) & 1.8 & 2.2 & 1.7 & 2.0 & 2.5 & 1.3 & 1.7 & 2.0 & 3.3 & 3.9 \\
Isoleucine (Ile) & 7.7 & 7.9 & 6.6 & 6.2 & 7.0 & 4.8 & 3.4 & 6.2 & 6.5 & 3.2 \\
Leucine (Leu) & 12.0 & 12.7 & 15.8 & 10.2 & 11.2 & 8.2 & 8.9 & 10.8 & 17.0 & 12.7 \\
Phenylalanine (Phe) & 7.4 & 8.0 & 6.4 & 6.8 & 7.6 & 4.4 & 3.1 & 7.7 & 6.9 & 4.4 \\
Lysine : methionine & 5.8 & 4.7 & 5.9 & 4.3 & 3.2 & 4.6 & 4.4 & 3.8 & 1.7 & 1.1 \\
EAA & 61.5 & 71.7 & 63.7 & 57.9 & 62.0 & 43.5 & 40.1 & 57.8 & 66.0 & 44.1 \\
\hline
\end{tabular}

AA - amino acid, CP - crude protein, EAA - essential amino acid, RS - raw soybean, SM - soybean meal, TS - Hyterso (toasted soybean), SP - Soypass (soybean meal treated with xylose ), CGM - corn gluten meal, CGF - corn gluten feed, RC - rapeseed cake, SC -sunflower cake, BGD - brewers grain dehydrated, $\mathrm{MC}$ - malt culms

for soybean products, from 8.5 to $10.5 \mathrm{~g} / \mathrm{kg}$ of $\mathrm{CP}$ (Table 4), but the mean of less absorbable Met was only $1.9 \pm 0.2 \mathrm{~g} / \mathrm{kg}$ of CP. Remaining feeds (SC, RC, MC, BGD, CGF and CGM) had values of absorbable Lys in the range of $4.2-8.0 \mathrm{~g} / \mathrm{kg}$ of CP. CGF and CGM supplied more absorbable Met (mean $3.6 \pm 0.4 \mathrm{~g} / \mathrm{kg}$ of CP) than products of soybean and of the other analysed feeds. RC and MC supplied less absorbable EAA compared with other feeds.

\section{Discussion}

The goal of improved efficiency of transfer of dietary protein into milk protein is to develop models of evaluation of the intestinal digestibility of RUP and AA of RUP. There are various treatments affecting the ruminal degradability and intestinal digestibility of $\mathrm{CP}$ from various protein feeds (Stern et al. 2006). Effects of thermal treatment on the rumen degradability of CP and intestinal digestibility of RUP that were observed in this study are consistent with the findings of several studies evaluating protein feeds. Stern et al. (2006) estimated RUP of processed soybean products from 23.2 to $68.3 \%$, and the intestinal digestibility of protein for non-enzymatically browned soybean meal ranged from $57.7 \%$ to $83.8 \%$, respectively. Thermal treatment of feeds is a common method that can be performed in a number of ways, including moist heat treatment with a positive relationship between steam pressure and temperature (Van der Poel et al. 2005). Several studies demonstrated that it is possible to move protein digestion of different oilseed feedstuffs from the rumen to the small intestine by heat treatment without decreasing the total digestibility. The values of ruminal degradation of CP for soybean meal (Mjoun et al. 2010) and extruded soybean meal (Borucki Castro et al. 2007) were consistent with similar findings in the literature. Lower ruminal degradation of $\mathrm{CP}$ from expeller soybean meal compared to soybean meal was previously reported (Borucki Castro et al. 2007). It was considered as a result of protein solubility reduction and denaturation caused by thermal treatment. Ruminal degradation of AA may be affected by the type of protein in the feedstuffs and their inherent characteristics and AA profiles, and also by different processing methods (Mjoun et al. 2010; Zralý and Písaříková 2009). Ruminal degradation of AA followed a similar pattern to that of CP for different feedstuffs. Increases in RUP often lead to a 
reduction of RDP and changes in absorbed AA. This intestinal digestibility coefficient is similar to the NRC (2001) assumption of $80 \%$, but the reported estimates are also highly variable ranging from $59.2-95.0 \%$. The wide range of reported estimates of intestinal digestibility of RUP and the number of differing methods used to estimate it illustrate the need for additional study of factors which influence the intestinal digestibility of RUP in ruminant feeds.

In dairy nutrition, Lys is an important nutrient representing $16.0 \%$ of the total essential AA contained in milk (NRC 2001). Lys is usually the most sensitive AA to be affected by methods used to protect proteins from ruminal degradation and is often lost at levels $5 \pm 15 \times$ higher than other AA. Currently, data reported in the literature on the intestinal digestibility of AA of RUP for individual feedstuffs are insufficient to incorporate AA of RUP digestibility coefficient into nutritional models. Therefore, further research is needed to measure the variation in the intestinal digestibility of AA of RUP within and among feeds. Differences in absorbable AA among feedstuffs resulted mainly from differences in the rumen degradability and degree of digestion in the small intestine. The prevalent factor contributing to differences in availability of AA between our study and the studies by Mjoun et al. (2010); Borucki Castro et al. (2007); and Kleins chmit et al. (2007) was a difference in the rumen degradability and intestinal digestibility. The values of IADP of estimated feeds will help to control the quality of protein feeds as sources of RUP for ruminants. Results of different studies indicate that corn gluten meal (74\%) provided the largest amount of IADP, followed by non-enzymatically browned soybean meal $(39.4 \%)$ and mechanically extracted soybean meal at $41.3 \%$ (Stern et al. 2006). The value of IADP or absorbable AA can be used as a guideline to select protein supplements for high producing dairy cows. Such information concerning intestinal digestibility of AA of RUP and absorbable EAA is needed for the development of diet formulation models to optimize the AA nutrition of dairy cows.

\section{Acknowledgements}

This work was financially supported by the project VEGA 1/0970/11.

\section{References}

Borucki Castro SI, Phillip LE, Lapierre H, Jardon PW, Berthiaume R 2007: Ruminal degradability and intestinal digestibility of protein and amino acids in treated soybean meal products. J Dairy Sci 90: 810-822

Committee Regulation ES No. 152/2009 of January 27, 2009

Gargallo S, Calsamiglia S, Ferret A 2006: Technical note: A modified three-step in vitro procedure to determine intestinal digestion of proteins. J Anim Sci 84: 2163-2167

Huhtanen P, Hristov AN 2009: A meta-analysis of the effects of dietary protein concentration and degradability on milk protein yield and milk N efficiency in dairy cows. J Dairy Sci 92: 3222-3232

Hvelplund T, Nørgaard P 2003: Ruminant Nutrition and Physiology. Nutrient turnover and feed evaluation. DJF Rapport Husdyrbrug 53. DJF, Tjele, Denmark, $601 \mathrm{p}$.

Kleinschmit DH, Anderson JL, Schingoethe DJ, Kalscheur KF, Hippen AR 2007: Ruminal and intestinal degradability of distiller's grains plus solubles varies by source. J Dairy Sci 90: 2909-2918

Mjoun K, Kalscheur KF, Hippen AR, Schingoethe DJ 2010: Ruminal degradability and intestinal digestibility of protein and amino acids in soybean and corn distillers' grains products. J Dairy Sci 93: 4144-4154

NRC (National Research Council) 2001: Nutrient requirements of dairy cattle. 7th rev. ed. National Academy Press, Washington, DC, $408 \mathrm{p}$.

Orskov ER, McDonald I 1979: The estimation of protein degradability in the rumen from incubation measurements weighted according to rate of passage. J Agric Sci Camb 92: 499-503

Prestløkken E, Rise O 2003: Protein and amino acid digestibility in dairy cows measured with mobile nylon bags recovered in ileum or in faeces. Acta Agric Scand Sect A Anim Sci 53: 11-20

Rulquin H, Vérité R, Guinard-Flament J, Pisulewski PM 2001: Amino acids truly digestible in the small intestine. Factors of variation in ruminants and consequences on milk protein secretion. INRA Prod Anim 14: 201-210

Stern MD, Bach A, Calsamiglia S 2006: New concepts in protein nutrition of ruminants. In 21th Annual Southwest 
Nutrition \& Management Conference Proceedings, February 23-24, 2006, Tempe, Arizona, University of Arizona: pp. 45-66

Van der Poel AFB, Prestlokken E, Goelema JO 2005: Feed processing: effects on nutrient degradation and digestibility. In Dijkstra J, Forbes JM, France J (Eds): Quantitative aspects of ruminant digestion and metabolism. 2nd ed. CABI Publishing, Wallingford, UK, pp. 627-661

Zralý Z, Písaříková B 2009: Nutritional value of lupine in the diets for pigs (a review). Acta Vet Brno 78: 399-409 